\title{
PENGEMBANGAN BAHAN AJAR FISIKA MELALUI PENDEKATAN STEM BERORIENTASI HOTS PADA MATERI USAHA DAN ENERGI
}

\author{
Dini Melani Putri Chania*, Rosane Medriati, Afrizal Mayub
}

Program Studi Pendidikan Fisika, Fakultas Keguruan dan Ilmu Pendidikan, Universitas Bengkulu,

Jl. W.R Supratman Kandang Limun, Bengkulu

e-mail ${ }^{*}$ dinimpc12@gmail.com

\begin{tabular}{c|c|c|c}
\hline Diterima 17 Juli 2020 & Direvisi 3 Agustus 2020 & Disetujui 20 Agustus 2020 & Dipublikasikan 30 Agustus 2020 \\
\hline \multicolumn{4}{c}{ https://doi.org/10.33369/jkf.3.2.109-120 } \\
\hline
\end{tabular}

\begin{abstract}
ABSTRAK
Penelitian ini bertujuan untuk mengembangkan bahan ajar fisika melalui pendekatan STEM berorientasi HOTS di SMAN Kota Bengkuku pada materi usaha dan energi. Produk yang dihasilkan berupa bahan ajar yang dapat digunakan guru dan siswa. Penelitian ini merupakan penelitian dan pengembangan (R\&D) dengan metode Sugiyono Level 1 yang dimodifikasi. Validasi produk dilakukan oleh ahli dengan menggunakan angket. Hasil validasi menunjukkan bahwa bahan ajar fisika ini dikategorikan sangat layak digunakan dengan persentase capaian 83,25\%. Persentase tersebut merupakan rata-rata dari aspek penilaian materi 82,5\%, aspek penilaian HOTS dan penilaian pendekatan STEM 81\%, aspek penilaian bahasa $86 \%$ dan aspek penilaian media $84 \%$. Dengan demikian dapat disimpulkan bahwa bahan ajar fisika melalui pendekatan STEM berorientasi HOTS di SMAN Kota Bengkulu pada materi usaha dan energi memenuhi kriteria dengan kualitas sangat layak sebagai salah satu media pembelajaran yang digunakan peserta didik SMA kelas $\mathrm{X}$.
\end{abstract}

Kata Kunci: Bahan ajar fisika, Pendekatan STEM, HOTS, Usaha dan energi.

ABSTRACT

This research was aimed to develop physics teaching material through HOTS oriented STEM approach in SMAN Kota Bengkulu on material of work and energy. The result of this product was teaching material which be used for teacher and student. This research was Research and Development (R\&D) with modified Sugiyono level 1 method. Product was validated by experts using questionnaires. Validation results showed that this physics teaching material was categorized as very proper to use with $83,25 \%$ achivement percentage. That percentage was average of $82,5 \%$ material evaluation aspect, $81 \%$ HOTS evaluation aspect and STEM approach evaluation, $86 \%$ language evaluation aspect and $84 \%$ media evaluation aspect. Therefore can be conclude that physics teaching material through HOTS oriented STEM approach in SMAN Kota Bengkulu on material of work and energy meet the criteria with very proper quality as one of learning media that use by grade $\mathrm{X}$ senior high school student.

Keyword: Physich teaching material, STEM approach, HOTS, work and energy.

\section{PENDAHULUAN}

Pendidikan merupakan salah satu aspek penting untuk kemajuan suatu negara, juga merupakan pembentuk karakter bangsa. Oleh karena itu, setiap warga negara memiliki hak untuk mendapatkan pendidikan yang layak. Dalam dunia pendidikan kurikulum bukanlah kata yang asing. Kurikulum dipahami sebagai seperangkat pengaturan mengenai tujuan isi dan bahan pelajaran serta cara yang digunakan sebagai pedoman penyelenggaraan kegiatan pembelajaran untuk mencapai tujuan pendidikan tertentu. Kurikulum 2013 adalah kurikulum terbaru yang diterapkan oleh Departemen Pendidikan Nasional mulai tahun 2013 sebagai bentuk pengembangan dari kurikulum sebelumnya yaitu kurikulum 2006 atau Kurikulum Tingkat Satuan Pendidikan yang mencakup kompetensi sikap, pengetahuan, dan keterampilan secara terpadu (1).

Kurikulum 2013 merupakan suatu kurikulum yang mengutamakan pemahaman, skill, dan pendidikan, berkarakter, siswa dituntut untuk paham atas materi aktif dalam berdiskusi dan 
presentasi serta memiliki sopan santun disiplin yang tinggi. Kurikulum 2013 menyandang harapan tinggi untuk mampu membentuk karakter bangsa Indonesia dan menyelesaikan masalah-masalah dalam dunia pendidikan Indonesia (2).

Pada implementasi Kurikulum 2013 di sekolah, guru salah satunya harus menggunakan pendekatan ilmiah (scientific), karena pendekatan ini lebih efektif hasilnya dibandingan pendekatan tradisional. Proses pembelajaran yang mengimplementasikan pendekatan saintifik akan menyentuh tiga ranah, yaitu sikap (afektif), pengetahuan (kognitif), dan keterampilan (psikomotor). Dengan proses pembelajaran yang demikian maka diharapkan hasil belajar melahirkan peserta didik yang produkif, kreatif, inovatif, dan afektif melalui penguatan sikap, keterampilan, dan pengetahuan yang terintegrasi (3).

Mengiringi peran guru dalam memfasilitasi kebutuhan siswa, penggunaan media sebagai perangkat pembelajaran semakin dibutuhkan untuk mengatasi permasalahan-permasalahan yang muncul karena keterbatasan waktu, tempat, dan fasilitas lainnya (4). Media adalah salah satu penentu keberhasilan belajar siswa. Kegiatan proses pembelajaran adalah informasi yang dipindahkan dari sumber ke informasi penerima melalui model dan media tertentu. Pembelajaran dengan model dan media yang emanrik dan dilengkapi dengan karakter hasanah suatu bangsa, siswa lebih menerima untuk mempelajari informasi untuk mencapai tujuan belajar (5). Bahan ajar merupakan salah satu perangkat pembelajaran yang dijadikan sebagai pedoman dan modal awal untuk mencapai hasil belajar. Maka dari itu, pendidik hendaknya memiliki inovasi untuk mengembangkan bahan ajar yang sesuai dengan rencana pembelajaran (4).

Masalah yang sering muncul dan dialami oleh peserta didik dalam pembelajaran adalah kesalahpahaman dalam mempelajari materi fisika. Penyebabnya karena pendidik hanya mengajarkan fisika yang bersifat abstrak melalui pembelajaran di kelas dan kurang diolengkapi dengan proses eksperimen laboratorium (praktikum). Kualitas pembelajaran fisika ditentukan oleh beberepa faktor, yaitu ketersediaan sarana, alat dan bahan laboratorium dan media pembelajaran yang baik untuk melaksakan proses pembelajaran (6).

Berdasarkan observasi yang telah dilakukan di SMAN 3 Kota Bengkulu didapatkan hasil bahwa penggunaan bahan ajar dengan pendekatan saintifik belum mendukung atau mengacu terhadap HOTS (Higher Order Thinking Skill). Bahan ajar yang digunakan oleh guru bersumber dari salah satu buku cetak yang mempunyai beberapa kelemahan antara lain: 1) soal-soal yang ada pada buku belum memenuhi indikator berpikir kritis, 2) tidak adanya permasahalan yang harus dipecahkan oleh siswa sehingga belum memenuhi indikator pemecahan masalah dan 3) komponen isi dalam buku tersebut masih kurang lengkap yaitu kurangnya penjabaran materi sehingga membuat siswa kesulitan untuk memahami pelajaran jika tidak dijelaskan secara rinci oleh guru. Sehingga bahan ajar dengan pendekatan saintifik yang digunakan di SMAN 3 Kota Bengkulu dapat dikatakan belum mencapai indikator HOTS.

Salah satu pendekatan pembelajaran lain yang sesuai dengan kurikulum 2013 adalah pendekatan STEM (7). Pendekatan STEM merupakan pendekatan pembelajaran yang menggabungkan dua atau lebih bidang ilmu yang termuat dalam STEM yaitu sains, teknologi, teknik/rekayasa dan matematika. Melalui pendekatan STEM diharapkan peserta didik memiliki keterampilan belajar dan berinovasi, yang meliputi berpikir kritis, kreatif, inovatif, serta mampu berkomunikasi dan berkolaborasi (8).

Peningkatan signifikan terhadap penguasaan konsep dan kemapuan berpikir kritis siswa dapat terjadi karena pembelajaran fisika dalam penelitian tersebut dibantu dengan bahan ajar berbasis STEM. Pembelajaran dilaksanakan sesuai dengan serangkaian proses yang terdapat dalam bahan ajar. Dengan demikian, siswa dapat menerima materi dengan baik melalui kegiatan diskusi, praktikum, presentasi, dan evaluasi yang dilakukan secara bertahap. Pembelajaran yang dikaitkan dengan aspek-aspek STEM memberikan kesempatan kepada siswa untuk memahami konsep fisika dipadukan teknologi, engineering dan matematika melalui kegiatan diskusi, praktikum dan pembuatan proyek (9). Kegiatan-kegiatan yang dilakukan selama proses pembelajaran tersebut dapat menarik minat siswa dan berimplikasi pada peningkatan hasil belajar. Pembelajaran dengan 
pendekatan STEM dapat memeberikan siswa pengalaman belajar, pembelajaran aktif dan bermakna serta kontekstual (10).

Sekolah mulai menerapkan pendekatan STEM dalam pembelajaran dengan harapan dapat meningkatkan kemampuan berpikir kritis dan pemecahan masalah siswa. Akan tetapi penerapan pendekatan STEM yang dilakukan oleh SMAN 3 Kota Bengkulu belum menggunakan media (bahan ajar) berbasis HOTS. Bahan ajar yang digunakan hanya 30\% yang memenuhi indikator HOTS. Oleh karena itu, dilakukanlah penelitian dengan judul Pengembangan Bahan Ajar Fisika melalui Pendekatan STEM Berorientasi HOTS pada Materi Usaha dan Energi dengan tujuan penelitian: 1) mendeskripsikan karakteristik bahan ajar fisika melalui pendekatan STEM berorientasi HOTS pada materi usaha dan energi yang dikembangkan dan 2) mendeskripsikan kelayakan bahan ajar fisika melalui pendekatan STEM berorientasi HOTS pada materi usaha dan energi berdasarkan judgement ahli.

\section{METODE PENELITIAN}

Jenis penelitian ini adalah penelitian pengembangan (research and development). Metode penelitian dan pengembangan (research and development) adalah metode penelitian yang digunakan untuk menghasilkan produk tertentu, dan menguji keefektifan produk tersebut (11). Adapun langkah-langkah metode Research and Development (R\&D) level 1 yang telah dimodifikasi digambarkan sebagai berikut:

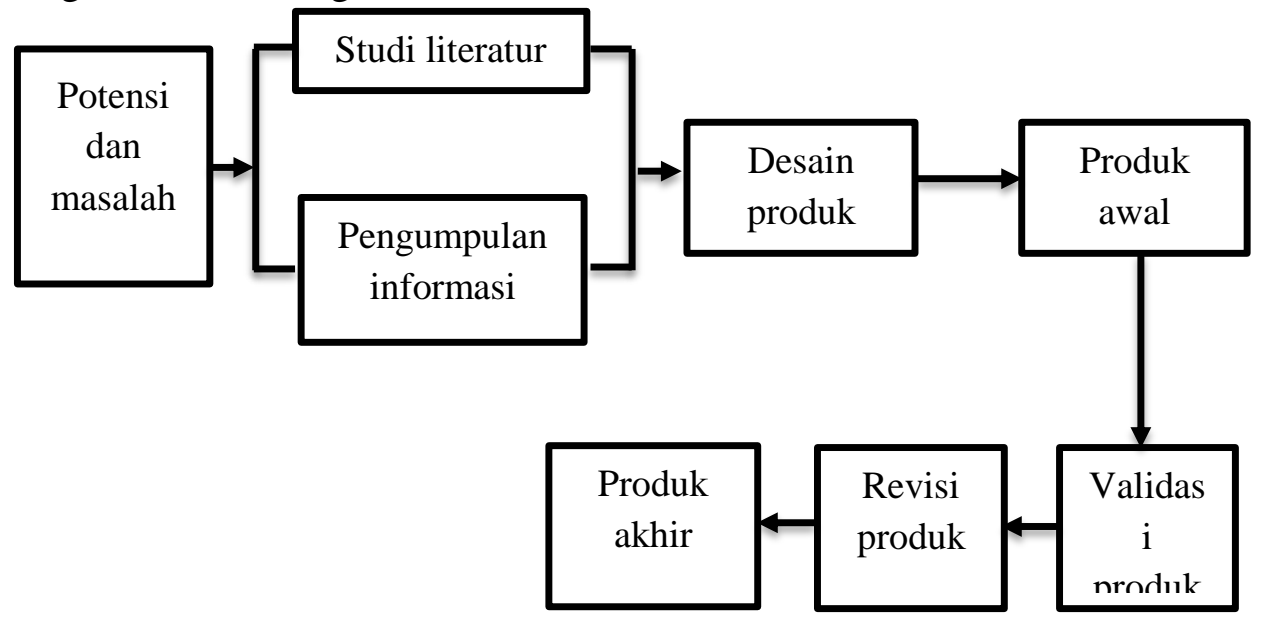

Gambar 1. Langkah-langkah R\&D level 1 yang dimodifikasi

Teknik pengumpulan data pada penelitian ini dilakukan melalui tiga tahap yaitu pada tahap menentukan potensi dan masalah dengan mengidentifikasi tingkat kebutuhan bahan ajar berorientasi HOTS dengan pendekatan STEM yaitu melakukan observasi, kedua yaitu dengan memberikan angket kebutuhan untuk menentukan produk apa yang akan dikembangkan, dan ketiga yaitu memberikan angket validasi terhadap produk yang telah dikembangkan menggunakan skala Likert dengan alternatif lima jawaban.

Ada tiga instrumen R\&D level 1 pada penelitian ini yaitu lembar observasi untuk mengetahui potensi dan masalah tentang kebutuhan bahan ajar, angket kebutuhan untuk mengidentifikasi tingkat kebutuhan produk yang dikembangkan, lembar angket validasi produk berupa angket validasi untuk mengetahui valid atau tidaknya produk yang dikembangkan.

Data yang diperoleh terdapat dua macam yaitu data kualitatif dan data kuantitatif. Data kualitatif berisi tentang komentar ahli materi, media, dan respon siswa. Data kuantitatif diperoleh dari penilaian kualitas materi bahan ajar dan penilaian media. Analisis data kuantitatif yaitu analisis data dengan mengadakan perhitungan-perhitungan yang relevan dengan masalah yang dianalisis. Analisis kuantitatif digunakan untuk menganalisis data yang terkumpul dari angket. Data dari angket dianalisis untuk mendapatkan gambaran tentang media pembelajaran. Kategori penilaian yang digunakan adalah skala Likert yang terdiri dari 5 altrernatif jawaban. Sebelum melakukan penilaian, maka dicari terlebih dahulu nilai rata-rata dari angket validasi. Untuk mencari nilai ratarata dapat menggunakan formula: 


$$
\bar{X}=\frac{\Sigma X}{N}
$$

dengan $\bar{X}$ adalah rata-rata nilai, $\sum X$ adalah jumlah total skor, dan $\mathrm{N}$ adalah banyaknya indikator (12).

Sebelum mencari skor rata-rata keseluruhan, dicari terlebih dahulu skor individu. Perhitungan persentase skor yang dapat dihitung dengan menggunakan formula:

$$
\text { Persentase } \operatorname{skor}(\%)=\frac{\text { skor }_{\text {rata-rata }}}{\text { skor }_{\text {tertinggi }}} \times 100 \%
$$

Setelah didapat persentase skor, maka selanjutnya mengukur interpreatsi skor. Interpretasi skor dihitung berdasarkan skor perolehan tiap butir. Untuk skala Likert dengan pencapaian skor interpretasi skala Likert bisa dilihat pada tabel 1, yaitu

Tabel 1. Interpretasi Kelayakan (13).

\begin{tabular}{cccl}
\hline No & $\begin{array}{c}\text { Tingkat } \\
\text { Pencapaian }\end{array}$ & Kualifikasi & \multicolumn{1}{c}{ Keterangan } \\
\hline 1. & $81-100 \%$ & Sangat baik & Sangat layak / tidak perlu direvisi \\
2. & $61-80 \%$ & Baik & Layak/ tidak perlu revisi \\
3. & $41-60 \%$ & Cukup baik & Kurang layak / perlu direvisi \\
4. & $21-40 \%$ & Kurang baik & Tidak layak / perlu direvisi \\
$\mathbf{5 .}$ & $<20 \%$ & Sangat kurang baik & Sangat tidak layak/ / perlu direvisi \\
\hline
\end{tabular}

\section{HASIL DAN PEMBAHASAN}

\subsection{Hasil}

\subsubsection{Potensi dan Masalah}

Adapun potensi yang ditemukan di salah satu SMA, yakni SMAN 3 Kota Bengkulu adalah SMAN tersebut sudah mulai menerapkan pendekatan STEM dan HOTS dalam pembelajaran serta juga ditemukannya masalah yaitu: (1) bahan ajar yang digunakan belum mengacu terhadap HOTS, (2) bahan ajar yang digunakan belum menerapkan pendekatan STEM dan (3) bahan ajar yang digunakan kurang menarik minat siswa dalam belajar.

\subsubsection{Studi Literatur dan Pengumpulan Informasi}

Penelitian ini didukung oleh penelitian mengenai pengembangan modul matematika dengan pendekatan science, technology, engineering, and mathematics (STEM) pada materi segiempat, didapatkan hasil bahwa matematika dengan pendekatan STEM pada materi segiempat sangat layak untuk digunakan dalam pembelajaran di kelas (14). Kemudian penelitian mengenai bahan ajar berbasis stem (science, technology, engineering, and mathematics) untuk meningkatkan penguasaan konsep siswa SMA, didapatkan hasil bahwa peningkatan yang signifikan terhadap penguasaan konsep siswa dapat terjadi karena pembelajaran fisika dalam penelitian ini dibantu dengan bahan ajar berbasis STEM (9). Selanjutnya penelitian mengenai pengembangan modul IPA berbasis proyek terintegrasi STEM pada materi tekanan, didapatkan hasil modul IPA berbasis proyek terintegrasi STEM pada meteri tekanan yang dikembangkan layak digunakan sebagai sumber belajar untuk siswa SMP karena pemilihan proyek yang sesuai dengan kemampuan siswa sehingga tidak ada proyek yang dapat menyulitkan siswa dalam menyelesaikan proyek tersebut. Pengumpulan informasi mengenai kebutuhan bahan ajar fisika dilakukan dengan menggunakan lembar angket analisis kebutuhan guru dan siswa (15).

\subsubsection{Desain Produk}

Langkah awal yang dilakukan dalam desain produk yaitu dengan merencanakan perumusan unit bahan ajar terlebih dahulu, meliputi silabus, kompetensi inti dan kompetensi dasar serta materi pembelajaran, dimana materi pembelajaran yang akan digunakan dalam penelitian dan pengembangan ini adalah materi usaha dan energi. Berdasarkan silabus, kompetensi dasar yang harus dikuasai siswa pada materi usaha dan energi yaitu: 3.9) Menganalisis konsep energi, usaha (kerja), hubungan usaha (kerja) dan perubahan energi, hukum kekekalan energi, serta penerapannya dalam peristiwa sehari-hari, 4.9) Menerapkan metode ilmiah untuk mengajukan gagasan 
penyelesaian masalah gerak dalam kehidupan sehari-hari, yang berkaitan dengan konsep energi, usaha (kerja) dan hukum kekekalan energi.

\subsubsection{Produk Awal}

Adapun produk awal pada pengembahan bahan ajar melalui pendekatan STEM berorientasi HOTS pada materi usaha dan energi adalah
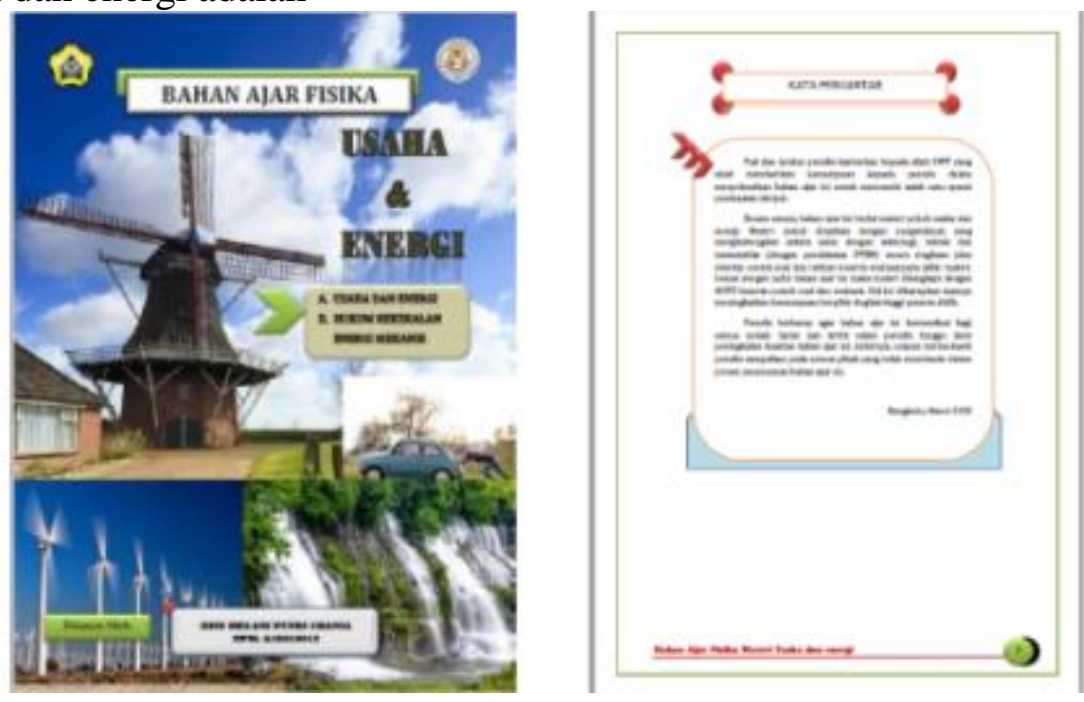

Gambar 2. Cover dan Kata Pengantar
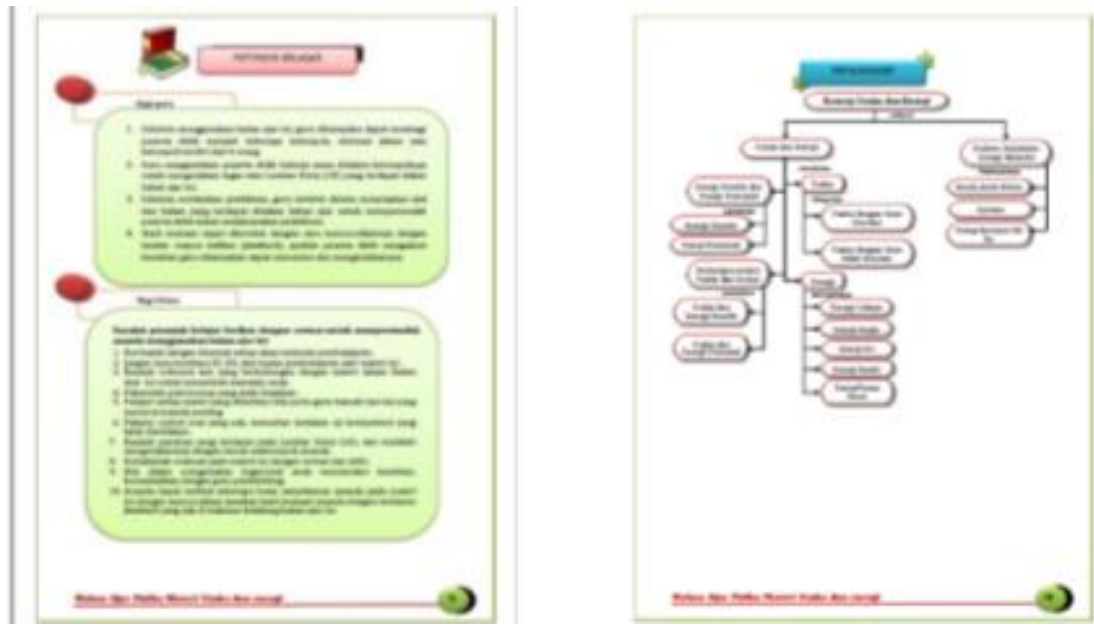

Gambar 3. Petunjuk Belajar dan Peta Konsep
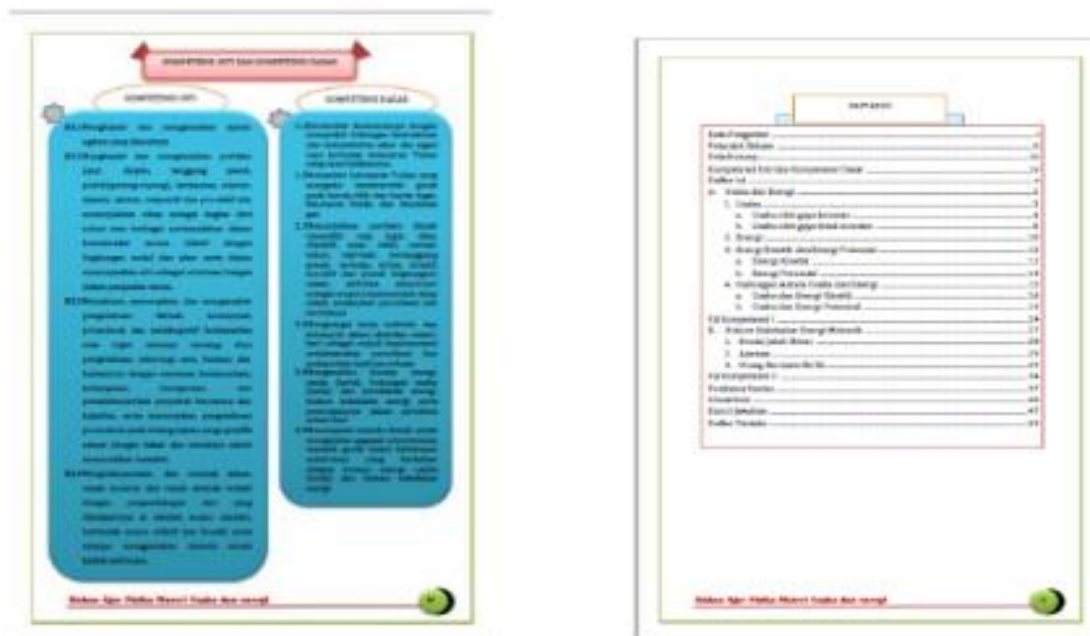

Gambar 4. Kompetensi Inti, Kompetensi Dasar dan Daftar Isi 

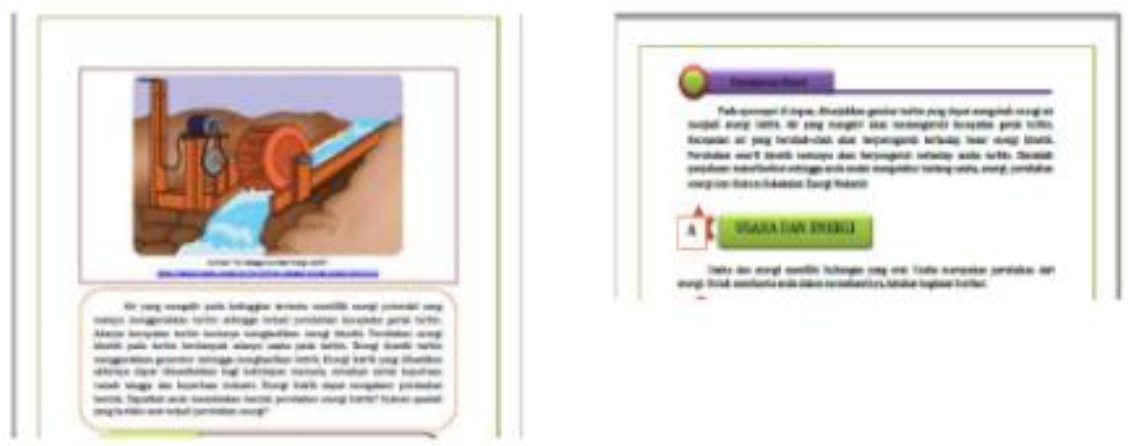

Gambar 5. Apersepsi dan Pendalaman Materi
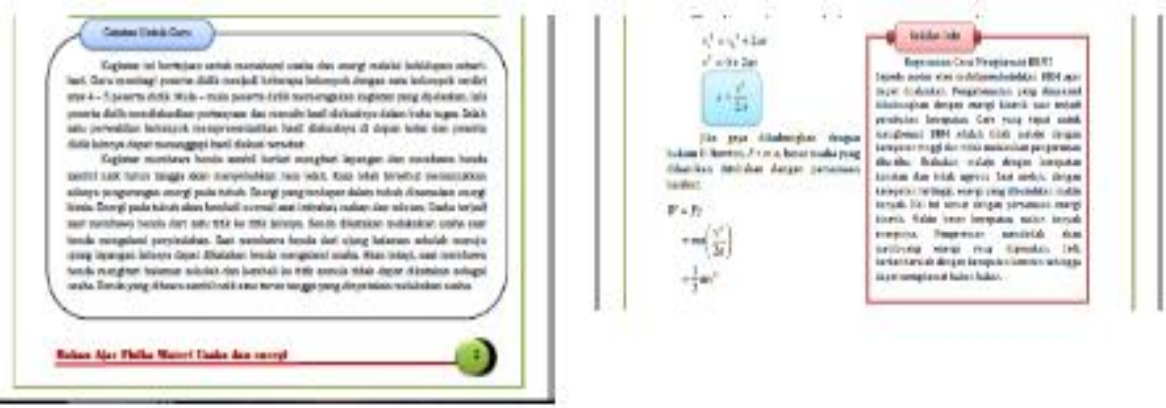

Gambar 6. Catatan untuk Guru dan Sekilas Info
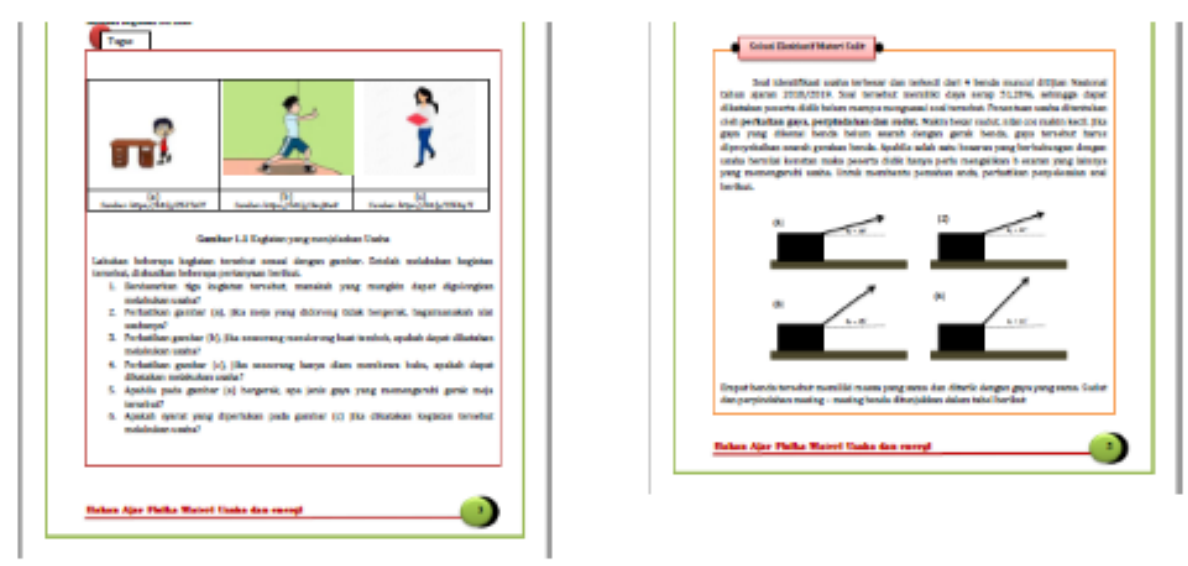

Gambar 7. Tugas dan Solusi Efektif
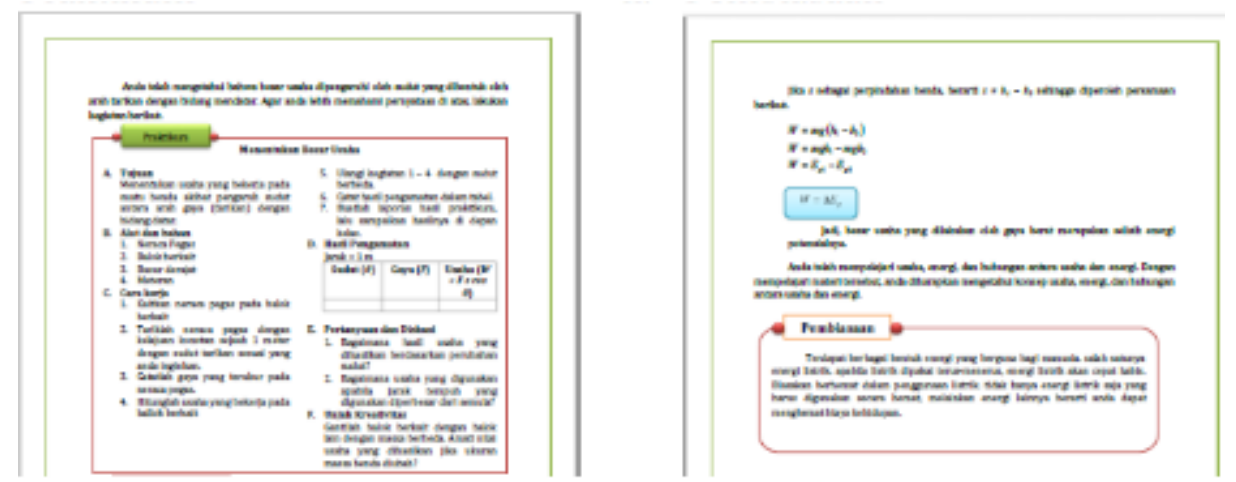

Gambar 8. Praktikum dan Pembahasan 

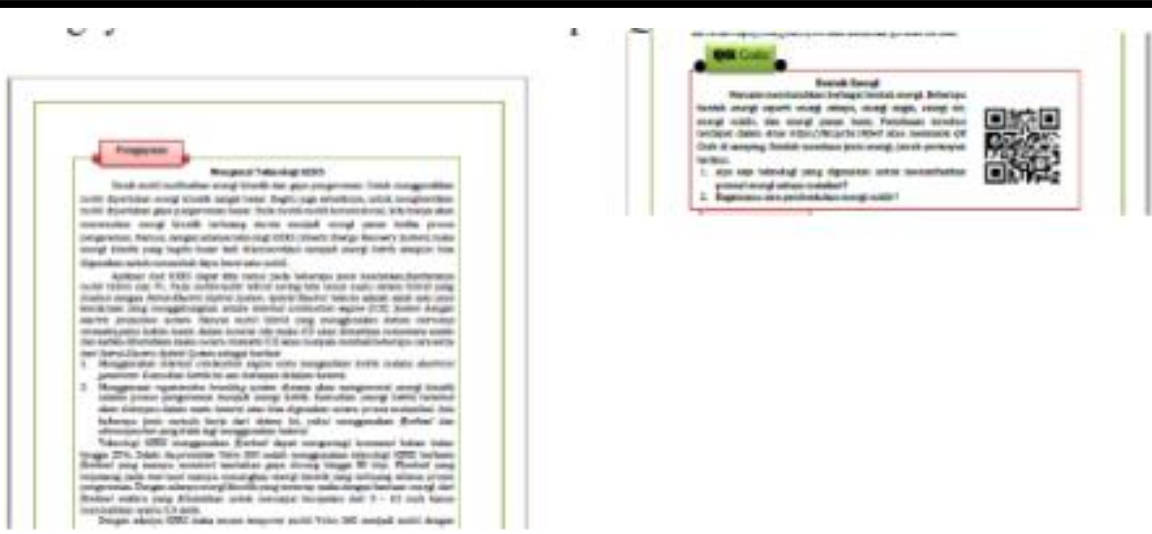

Gambar 9. Pengayaan dan QR Code
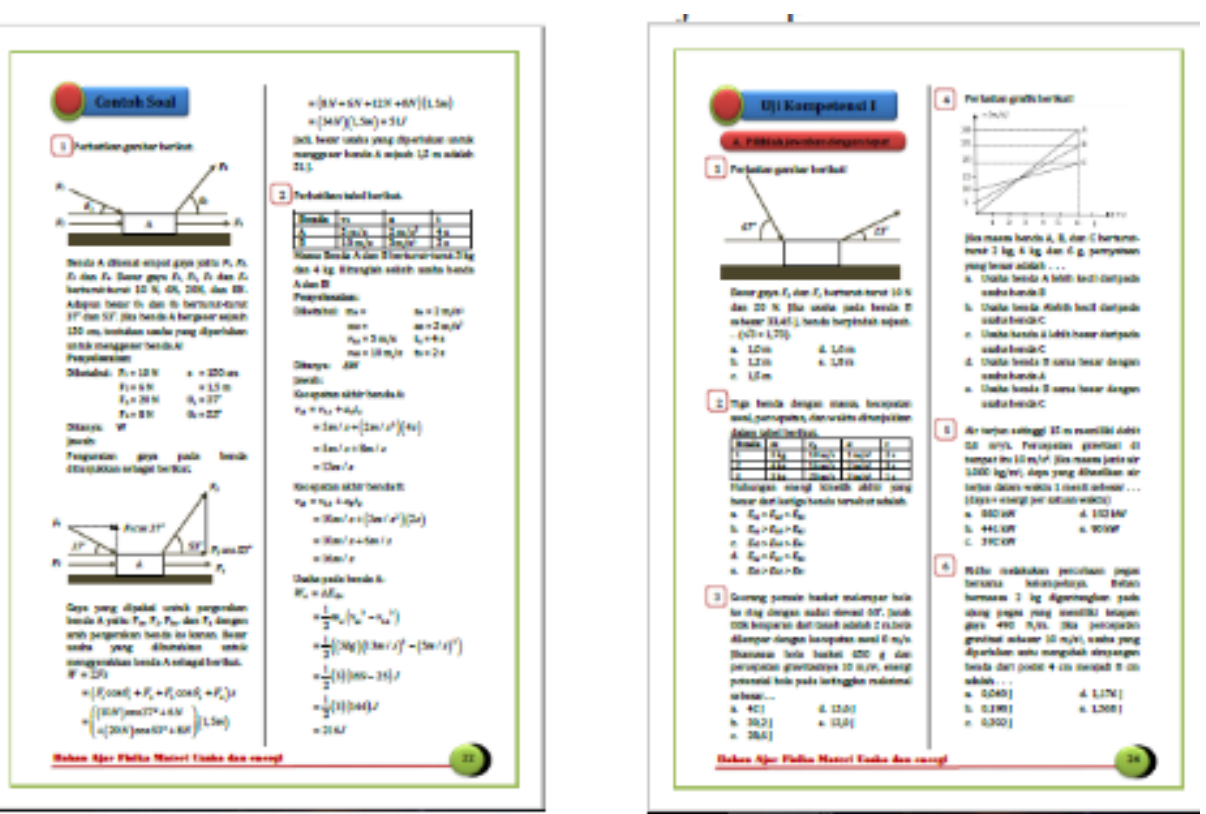

Gambar 10. Contoh Soal HOTS dan Uji Kompetensi
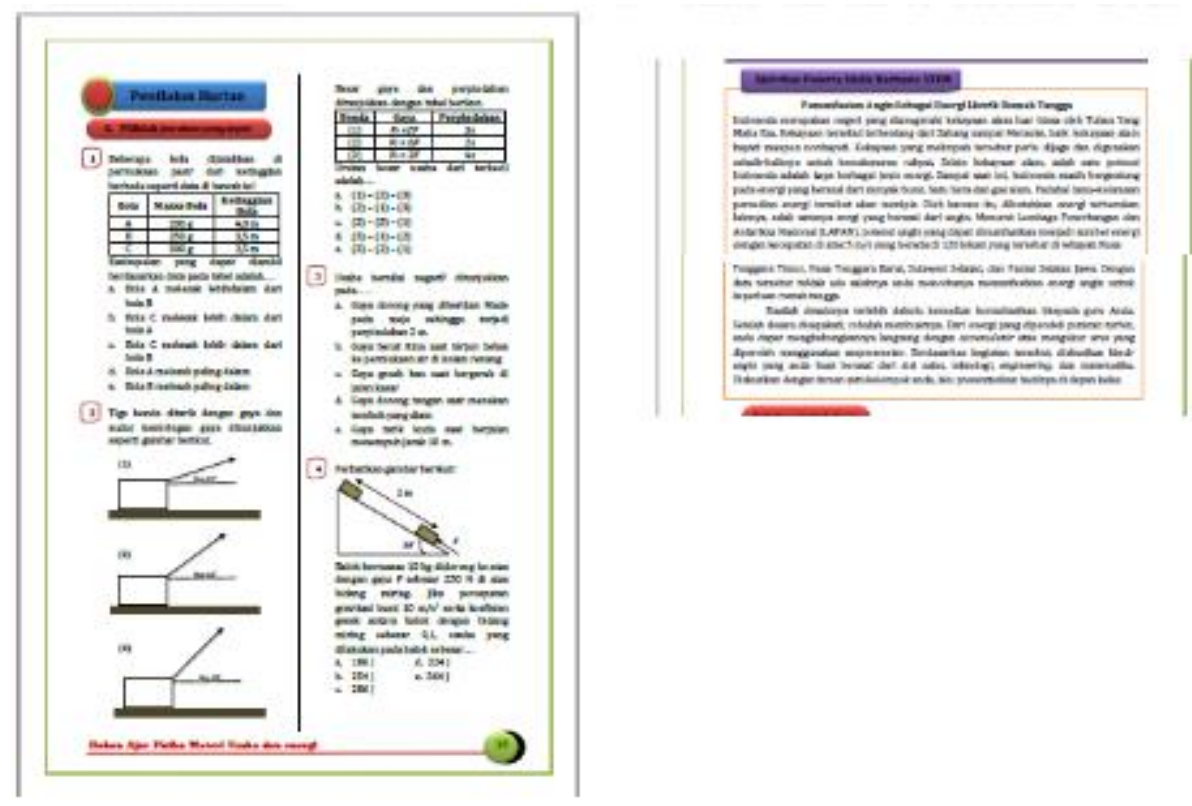

Gambar 11. Penilaian Harian dan Aktivitas Berbasis STEM 


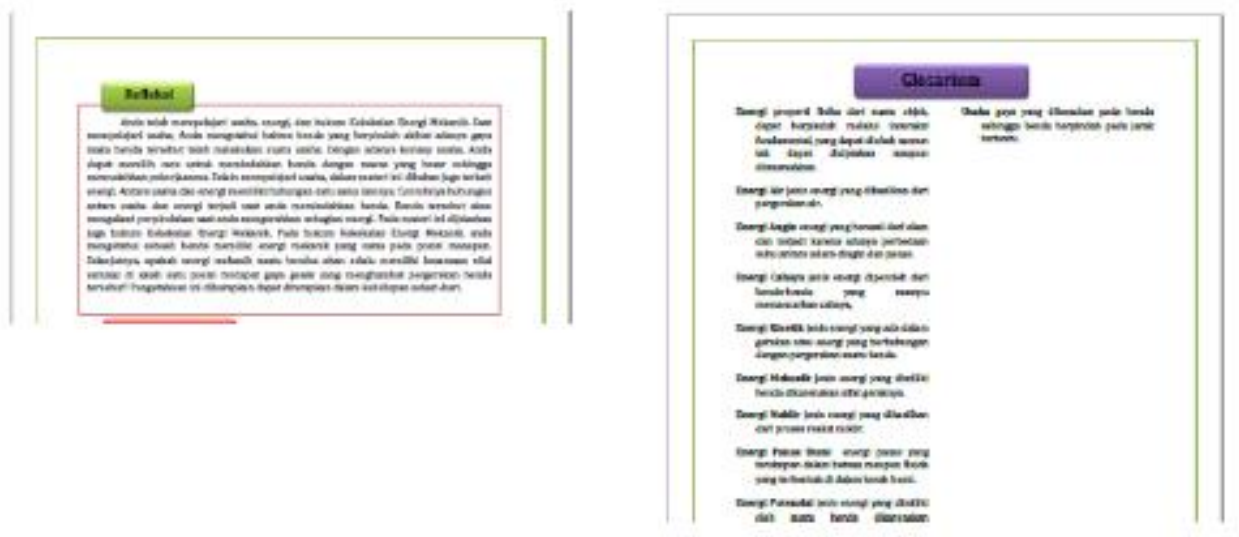

Gambar 12. Refleksi dan Glosarium
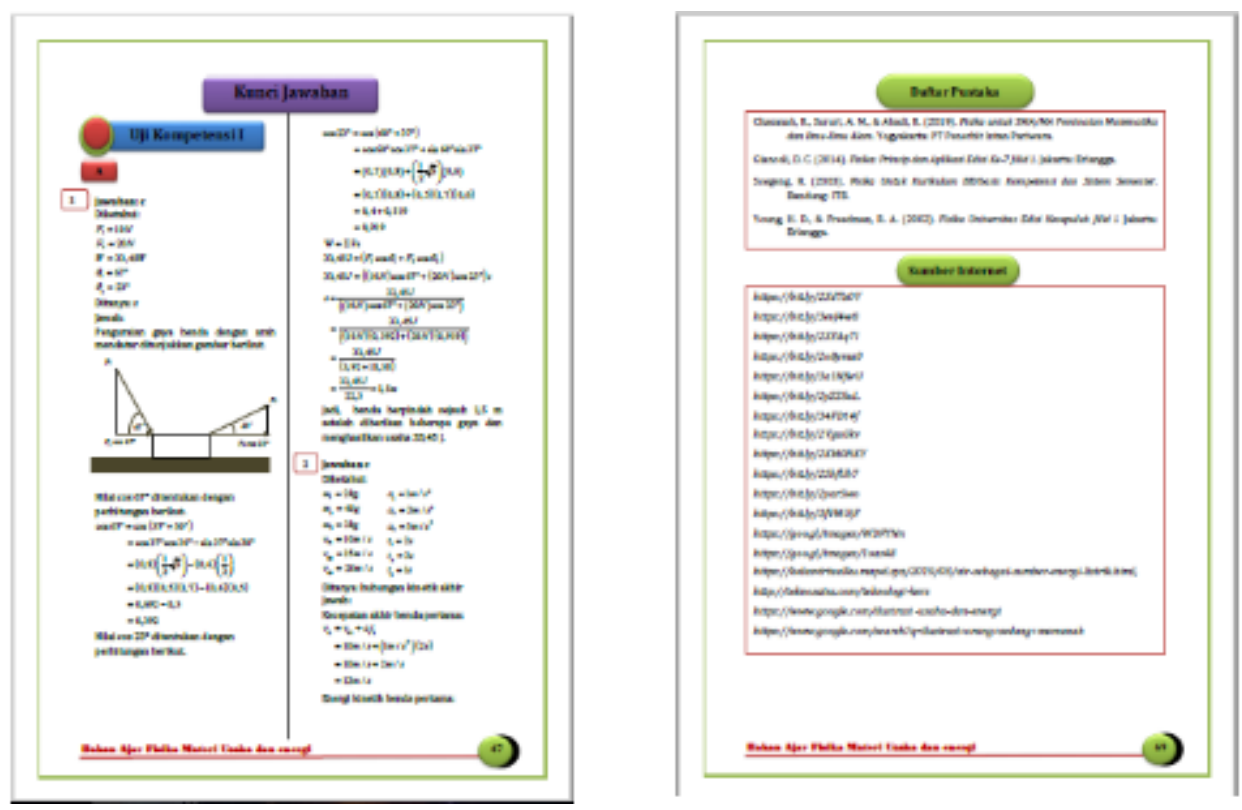

Gambar 13. Kunci Jawaban dan Daftar Pustaka

\subsubsection{Validasi Produk}

Hasil uji kelayakan pada aspek penilaian materi secara lebih jelas dapat dilihat dalam tabel 2 berikut.

Tabel 2. Hasil Uji Kelayakan pada Aspek Penilaian Materi

\begin{tabular}{cccccc}
\hline Validator & $\Sigma \mathrm{x}$ & $\begin{array}{c}\text { Skor } \\
\text { Tertinggi }\end{array}$ & Rata-rata & Presentase & Kategori \\
\hline Ahli I & 155 & 5 & 4,4 & $88 \%$ & $\begin{array}{c}\text { Sangat } \\
\text { Layak } \\
\text { Ahli II }\end{array}$ \\
\hline
\end{tabular}

Berdasarkan tabel 2 diketahui hasil uji kelayakan pada aspek penilaian materi yang berjumlah 35 butir penilaian yang dilakukan oleh ahli I, didapatkan bahwa draft bahan ajar fisika melalui pendekatan STEM berorientasi HOTS pada materi usaha dan energi yang telah dibuat berada pada kategori sangat layak yaitu dengan presentase $88 \%$. Kemudian hasil uji kelayakan materi yang dilakukan oleh ahli II didapat bahwa bahan ajar fisika melalui pendekatan STEM berorientasi HOTS juga berada dalam kategori layak dengan presentase $77 \%$.

Hasil uji kelayakan pada aspek penilaian HOTS dan penilaian pendekatan STEM secara lebih jelas dapat dilihat dalam tabel 3 berikut.

Tabel 3. Hasil Uji Kelayakan pada Aspek Penilaian HOTS dan Penilaian STEM

\begin{tabular}{cccccc}
\hline Validator & $\Sigma \mathrm{x}$ & $\begin{array}{c}\text { Skor } \\
\text { Tertinggi }\end{array}$ & Rata-rata & Presentase & Kategori \\
\hline Ahli I & 137 & 5 & 4,42 & $88 \%$ & Sangat Layak \\
\hline
\end{tabular}




\begin{tabular}{cccccc}
\hline Validator & $\Sigma \mathrm{x}$ & $\begin{array}{c}\text { Skor } \\
\text { Tertinggi }\end{array}$ & Rata-rata & Presentase & Kategori \\
\hline Ahli II & 115 & 5 & 3,71 & $74 \%$ & Layak \\
\hline
\end{tabular}

Berdasarkan tabel 3, diketahui uji kelayakan pada aspek penilaian HOTS dan penilaian STEM yang berjumlah 31 butir penilaian yang dilakukan oleh ahli I, didapatkan bahwa bahan ajar fisika melalui pendekatan STEM berorientasi HOTS pada materi usaha dan energi yang sudah dibuat berada dalam kategori sangat layak yaitu dengan persentase $87 \%$. Kemudian hasil uji kelayakan aspek penilaian HOTS dan pendekatan STEM yang dilakukan oleh ahli II didapat bahwa bahan ajar fisika melalui pendekatan STEM berorientasi HOTS juga berada dalam kategori layak dengan presentase $74 \%$.

Hasil uji kelayakan pada aspek bahasa secara lebih jelas dapat dilihat dalam tabel 4 berikut. Tabel 4 Hasil Uji Kelayakan pada Aspek Penilaian Bahasa

\begin{tabular}{cccccc}
\hline Validator & $\Sigma \mathrm{x}$ & $\begin{array}{c}\text { Skor } \\
\text { Tertinggi }\end{array}$ & Rata-rata & Presentase & Kategori \\
\hline Ahli I & 56 & 5 & 4,3 & $86 \%$ & Sangat Layak \\
Ahli II & 56 & 5 & 4,3 & $86 \%$ & Sangat Layak \\
\hline
\end{tabular}

Berdasarkan tabel 4, diketahui uji kelayakan pada aspek penilaian bahasa yang berjumlah 13 butir penilaian yang dilakukan oleh ahli I, didapatkan bahwa bahan ajar fisika melalui pendekatan STEM berorientasi HOTS pada materi usaha dan energi yang sudah dibuat berada dalam kategori sangat layak yaitu dengan persentase $86 \%$. Kemudian hasil uji kelayakan aspek penilaian bahasa yang dilakukan oleh ahli II didapat bahwa bahan ajar fisika melalui pendekatan STEM berorientasi HOTS juga berada dalam kategori sangat layak dnegan presentase $86 \%$.

Hasil uji kelayakan pada aspek bahasa secara lebih jelas dapat dilihat dalam tabel 5 berikut. Tabel 5 Hasil Uji Kelayakan pada Aspek Penilaian Media

\begin{tabular}{cccccc}
\hline Validator & $\Sigma \mathrm{x}$ & $\begin{array}{c}\text { Skor } \\
\text { Tertinggi }\end{array}$ & Rata-rata & Presentase & Kategori \\
\hline Ahli I & 137 & 5 & 4,4 & $88 \%$ & Sangat Layak \\
Ahli II & 124 & 5 & 4 & $80 \%$ & Sangat Layak \\
\hline
\end{tabular}

Berdasarkan tabel 5, diketahui uji kelayakan pada aspek penilaian media yang berjumlah 31 butir penilaian yang dilakukan oleh ahli I, didapatkan bahwa bahan ajar fisika melalui pendekatan STEM berorientasi HOTS pada materi usaha dan energi yang sudah dibuat berada dalam kategori sangat layak yaitu dengan persentase $88 \%$. Kemudian hasil uji kelayakan aspek penilaian media yang dilakukan oleh ahli II didapat bahwa bahan ajar fisika melalui pendekatan STEM berorientasi HOTS juga berada dalam kategori sangat layak dengan persentase $80 \%$.

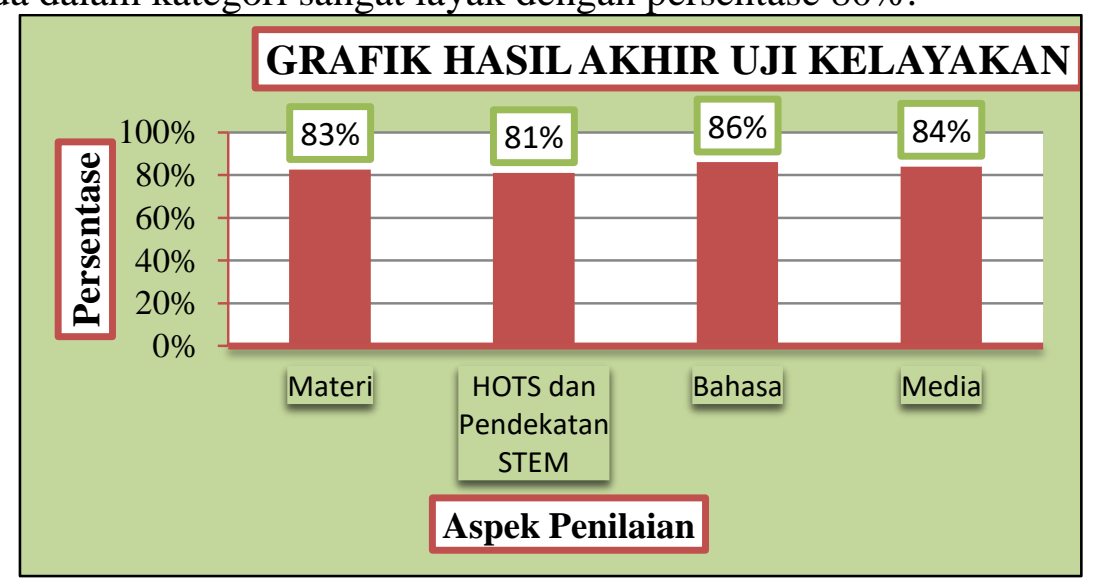

Gambar 14. Grafik Hasil Uji Kelayakan

Berdasarkan Gambar 14 dapat diketahui hasil akhir uji kelayakan. Pada aspek penilaian materi didapatkan rata-rata sebesar $83 \%$. Pada aspek penilaian HOTS dan pendekatan STEM didapatkan rata-rata sebesar $81 \%$. Pada aspek penilaian bahasa didapatkan rata-rata sebesar $86 \%$ dan pada aspek penilaian media didapatkan rata-rata sebesar $84 \%$. 


\subsubsection{Revisi Produk}

Pada tahap ini dilakukan revisi berdasarkan saran dan masukan dari validator. Revisi mengenai produk berupa draft bahan ajar fisika melalui pendekatan STEM berorientasi HOTS adalah tentang kepenulisan ukuran huruf untuk keterangan gambar, yang mana ukuran hurufnya masih bermacammacam, kemudian ada penambahan indikator dan tujuan pembelajaran, penambahan contoh soal, perbaikan gambar dan struktur kalimat serta penambahan materi agar lebih lengkap.

\subsubsection{Produk Akhir}

Setelah melakukan revisi draft bahan ajar melalui pendekatan STEM berorientasi HOTS yang sudah dikembangkan maka produk berupa bahan ajar fisika melalui pendekatan STEM berorientasi HOTS ini sudah menjadi produk akhir dimana produk akhir merupakan tahap akhir dari penelitian Reseacrh and Development (R\&D) level 1 yang dimodifikasi.

\subsection{Pembahasan}

Pengembangan bahan ajar fisika melalui pendekatan STEM berorientasi HOTS merupakan produk dalam penelitian ini menggunakan langkah-langkah penelitian R\&D Level 1 yang dimodifikasi, yaitu: potensi dan masalah, studi literatur dan pengumpulan informasi, desain produk, produk awal, validasi produk, revisi produk dan produk akhir. Tujuan pengembangan produk ini adalah: 1) mendeskripsikan karakteristik bahan ajar fisika melalui pendekatan STEM berorientasi HOTS dan 2) menghasilkan draft bahan ajar fisika melalui pendekatan STEM berorientasi HOTS pada materi usaha dan energi yang layak dan bisa digunakan untuk dicobakan sebagai referensi dalam mengembangkan bahan ajar fisika pada materi lainnya.

Penelitian ini mengacu pada penelitian mengenai bahan ajar berbasis STEM (Science, Technlogy, Engineering, and Mathematics) untuk meningkatkan penguasaan konsep siswa SMA, yang mana bahan ajar berbasis STEM yang dikembangkan pada penelitian tersebut terbagi menjadi tiga bagian, yaitu pendahuluan, isi dan penutup. Bagian pendahuluan terdiri dari halaman judul, kata pengantar, daftar isi, peta konsep, kompetensi dasar (KD), dan tujuan pembelajaran. Bagian isi terdiri dari uraian materi yang mana memuat 6 pokok bahasan dan bagian penutup terdiri dari rangkuman materi, uji kompetensi, glosarium dan daftar pustaka (9).

Adapun kelebihan dari pengembangan bahan ajar fisika melalui pendekatan STEM berorientasi HOTS pada materi usaha dan energi yaitu sudah lebih lengkap dan terdapat soal-soal yang mengacu terhadap HOTS. Komponen bahan ajar fisika melalui pendekatan STEM berorientasi HOTS terdiri dari: 1) kata pengantar, 2) petunjuk belajar, 3) peta konsep, 4) kompetensi inti dan kompetensi dasar, 5)indikator dan tujuan pembelajaran 6) daftar isi, 7) materi pembelajaran yang berisi: a) apersepsi, b) pendalaman materi, c) catatan untuk guru, d) cakap teknologi yang berisi tugas yang berkaitan dengan aplikasi TIK. Dengan demikian siswa dapat mengembangkan keterampilan dalam penggunaan program komputer, e) sekilas info yang berisi informasi untuk menambahkan wawasan siswa. Informasi itu dapat berupa tokok (ilmuwan), perkembangan IPTEK dan penerapan berbagai aplikasi ilmu pengetahuan, f) tugas, g) solusi eksklusif materi sulit, praktikum, pengayaan. Kemudian ada 8) QR Code yang berisi ajakan kepada perserta didik untuk membuka website berkaitan dengan materi yang dipelajari, 9) contoh soal, uji kompetensi dan penilaian harian yang berisi soal-soal C4, C5, dan C6, 10) refleksi yang berisi berisi ajakan untuk menemukan makna dan merenungkan manfaat pembelajaran, 11) glosarium, 12) kunci jawaban dan 13) daftar pustaka.

Pembelajaran yang aktif terjadi ketika siswa menjadi pusat pembelajaran, melalui pendekatan STEM siswa dibimbing untuk menemukan sendiri jawaban atas materi yang diajarkan, sehingga siswa terlibat aktif dalam pembelajaran (16).

\section{SIMPULAN DAN SARAN}

\subsection{Simpulan}

Berdasarkan penelitian yang telah dilakukan didapatkanlah kesimpulan yaitu: 1) karakteristik bahan ajar fisika melalui pendekatan STEM berorientasi HOTS antara lain terdapat soal-soal yang mengacu pada taksonomi Bloom C4, C5. dan C6, terdapat aktivitas siswa berupa proyek berbasis STEM, selain itu juga dilengkapi dengan kata pengantar, petunjuk belajar, peta konsep, kompetensi inti dan kompetensi dasar, indikator dan tujuan pembelajaran, daftar isi, materi pembelajaran yang 
berisi apersepsi, pendalaman materi, catatan untuk guru, cakap teknologi, sekilas info, tugas, solusi eksklusif materi sulit, praktikum, pengayaan, $Q R$ Code, refleksi, glosarium, kunci jawaban dan daftar pustaka, 2) kelayakan bahan ajar fisika melalui pendekatan STEM berorientasi HOTS berdasarkan aspek penilaian materi, aspek penilaian HOTS dan penilaian pendekatan STEM, aspek penilaian bahasa dan aspek penilaian media yaang dilakukan oleh 2 orang judgement ahli didapatkan presentase rata-rata yaitu $83,25 \%$ dan berada dalam kategori sangat layak.

\subsection{Saran}

Adapun saran dari penelitian ini antara lai: 1) bahan ajar yang dibuat memiliki keterbatasan dalam penelitian yaitu belum diujucobakan secara terbatas dan luas kepada siswa, sehingga untuk penelitian selanjutnya diharapkan dapat dujicobakan secara terbatas dan luas kepada siswa, 2) bahan ajar hanya menyajikan materi usaha dan energi saja sehingga diharapkan dapat dilakukan pengembangan pada materi yang lain, 3) untuk penelitian-penelitian selanjutnya perlu dikaji lebih dalam lagi mengenai materi fisika yang berkaitan dengan engineering dan teknologi untuk memperkaya pengetahuan dan pemahaman siswa, 4) untuk penelitian-penelitian selanjutnya sebaiknya ada soal dalam bentuk pertanyaan konsep dan mengacu pada taksonomi Bloom yang baru dimana ada proses kognitifnya.

\section{UCAPAN TERIMA KASIH}

Penulis mengucapkan terimakasih kepada validator ahli yaitu Bapak Dr. Eko Swistoro M. Pd dan Bapak Eko Risdianto M. Cs yang telah membantu memberikan penilaian, saran dan masukan dalam pengembangan bahan ajar ini.

\section{DAFTAR PUSTAKA}

1. Mardiana S, Sumiyatun S. Implementasi Kurikulum 2013 dalam Pembelajaran Sejarah di SMA Negeri 1 Metro. Historia Santiago. 2017 Mar 22;5(1):45.

2. Aqdwirida R. IMPEMENTASI KURIKULUM 2013 DI SMA NEGERI 2 MAGELANG. J Kebijak Pendidik. 2016;V(1):34-48.

3. Julfahnur, M MR, DIana S, Khalik I. Implementasi Kurikulum 2013 Dalam Pembelajaran Sma. $2013 ; 7-8$.

4. Sukiminiandari YP, Budi AS, Supriyati Y. Pengembangan Modul Fisika dengan Pendekatan Saintifik. Pros Semin Nas Fis. 2015;IV:161-4.

5. Melianti E, Risdianto E, Swistoro E. Pengembangan Media Pembelajaran Berbasis Multimedia Interaktif Menggunakan Macromedia Director Pada Materi Usaha Dan Energi Kelas X. J Kumparan Fis. 2020;3(1):1-10.

6. Sriwahyuni I, Risdianto E, Johan H. Pengembangan Bahan Ajar Elektronik Menggunakan Flip Pdf Professional Pada Materi Alat-Alat Optik Di Sma. J Kumparan Fis. 2019;2(3):145-52.

7. Gustiani I, Widodo A, Suwarma IR. Development and validation of science, technology, engineering and mathematics (STEM) based instructional material. AIP Conf Proc. 2017;1848(May).

8. Winarni J, Zubaidah S, H SK. STEM: apa, mengapa, dan bagaimana. Vol. 1, Prosiding Seminar Nasional Pendidikan IPA Pascasarjana UM. 2016. p. 976-84.

9. Pangesti KI, Yulianti D, Sugianto. Bahan Ajar Berbasis STEM (Science, Technology, Engineering, and Mathematics) untuk Meningkatkan Penguasaan Konsep Siswa SMA. 
2017;6(3).

10. Lestari DAB, Astuti B, Darsono T. Implementasi LKS Dengan Pendekatan STEM (Science, Technology, Engineering, And Mathematics) Untuk Meningkatkan Kemampuan Berpikir Kritis Siswa. J Pendidik Fis dan Teknol. 2018 Nov 5;4(2):202.

11. Sugiyono. METODE PENELITIAN DAN PENDIDIKAN Pendekatan Kuantitatif, Kualitatif, dan R\&D. Bandung: Alfabeta; 2010. 407 p.

12. Widiyanto MA. Statistika Terapan. Jakarta: PT Elex Media Komputindo; 2013. 40 p.

13. Hayati S, Budi AS, Handoko E. Pengembangan Media Pembelajaran Flipbook Fisika untuk Meningkatkan Hasil Belajar Peserta Didik. Pros Semin Nas Fis SNF2015. 2015;IV:49-54.

14. Utami TN, Jatmiko A, Suherman S. Pengembangan Modul Matematika dengan Pendekatan Science, Technology, Engineering, And Mathematics (STEM) pada Materi Segiempat. Desimal J Mat. 2018;1(2):165.

15. Sugianto SD, Ahied M, Hadi WP. Pengembangan Modul Ipa Berbasis Proyek Terintegrasi Stem. J Nat Sci Educ Res. 2018;1(1):28-39.

16. Khoiriyah N, Abdurrahman A, Wahyudi I. Implementasi pendekatan pembelajaran STEM untuk meningkatkan kemampuan berpikir kritis siswa SMA pada materi gelombang bunyi. J Ris dan Kaji Pendidik Fis. 2018;5(2):53. 